\title{
The development of audio-visual media with contextual teaching learning approach to improve learning motivation and critical thinking skills
}

\author{
Khairani Sarwinda ${ }^{1}$ *, Eli Rohaeti ${ }^{1}$, Mirra Fatharani ${ }^{2}$ \\ ${ }^{1}$ Universitas Negeri Yogyakarta. Jalan Colombo No. 1, Yogyakarta 55281, Indonesia \\ ${ }^{2}$ Monash University. Wellington Rd, Clayton VIC 3800, Australia \\ * Corresponding Author. E-mail: khairani_wiendha@yahoo.com
}

Received: 6 September 2018; Revised: 18 February 2020; Accepted: 7 April 2020

\begin{abstract}
The study aims at developing the valid Contextual Teaching-Learning (CTL) Approach-based audio visual learning media in order to improve the learning motivation and the critical thinking skills significantly and also at identifying the effectiveness level of the Contextual Teaching-Learning (CTL) Approach-based audio visual learning media in improving the students' learning motivation and critical thinking skills. Therefore, autoatically the nature of the study is research and development. During the conduct of the study, the data were gathered by using the random sampling technique. Then, the data gathering instruments that had been implemented were the media assessment questionnaire, the observation, the motivation questionnaire and the critical thinking skills test. The results of the study show that the Contextual Teaching-Learning (CTL) Approach-based audio-visual learning media that has been developed by using the Borg \& Gall model is considered valid. The students' learning motivation has increased as having been confirmed by the fact that the students are more enthusiastic, more interested and happier in attending to the learning process. Furthermore, the results of the students' critical thinking skills test in the experimental group show that 25 students have met the passing grade while the remaining 6 students have not met the passing grade. On the other hand, the results of the students' critical thinking skills test in the control group show that 20 students have met the passing grade while the remaining 12 students have not met the passing grade. In other words, these findings show that the learning process through the use of the Contextual Teaching-Learning (CTL) Approachbased audio-visual learning media is able to improve the students' learning motivation and critical thinking skills.
\end{abstract}

Keywords: CTL, critical thinking skills, audio visual media, learning motivation

How to Cite: Sarwinda, K., Rohaeti, E., \& Fatharani, M. (2020). The development of audiovisual media with contextual teaching learning approach to improve learning motivation and critical thinking skills. Psychology, Evaluation, and Technology in Educational Research, 2(2), 98-114. doi:http://dx.doi.org/10.33292/petier.v2i2.12

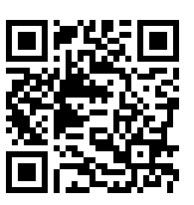

\section{INTRODUCTION}

The era of globalization demands the Human Resources quality that displays prominent competence. The improvement on the Human Resources competence might be pursued by improving the learning quality through the good design so that the cognitive, the affective and the psychomotor skills of the students might be improved. The learning process should be designed by the teacher as the facilitator in preparing the learning directions and objectives in order that the students will be actively involved within the learning process. In relation to the statement, the results of the preliminary observation toward the learning process of Chemistry in the Grade XI-5 of the State 6 Senior High School Yogyakarta on July $29^{\text {th }}, 2013$ show that the teachers have still been the center of the learning process (teacher-centered). In addition, the results of the preliminary observation also show that the teachers have also managed the learning process by only relying on the textbooks (textbook-oriented). As a result, the students become less active in attending to the learning process. In turn, the students attain less meaningful learning experiences. Within the learning process, the students should be 
dealing with the phenomena that have been taking place around them instead of being assigned to read textbooks and to work on the student worksheets. Therefore, it is no wonder that the students' critical thinking skills have become less developed.

In relation to the elaboration within the above paragraph, the learning process of Chemistry should link the concept, the principle, the theory and the implementation of Chemistry into the daily life context. The reason is that the learning process of Science and Technology is intended to cover the further competencies of Science and Technology and also to habituate critical, creative and independent-scientific thinking skills in accordance to the mandate of the Minister of National Education Regulation Number 22 of 2006. Unfortunately, in the practice the students are less able to retrieve the phenomena that have been taking place around them due to the fact that the students have not been accustomed to performing critical thinking skills; as a result, the students become less responsive toward the problems in their surrounding environment that might have been related to the learning materials (Nurdiyana, 2019). The critical thinking skills belong to the higher order thinking, which has been popularly known as HOTS. The critical thinking skills refer to the specific-cognitive capacity that the students display in their critical thinking habits. This capacity requires the students to be more able to both evaluate and synthesize instead of being able to only apply or analyse (Moore, 2009). An individual who possesses the critical thinking skills will realize the potential obstacles and difficulties and, therefore, he or she will always be ready to identify the approach that should be taken in solving the given problems systematically (Thompson, 2011, p. 2). As part of higher order thinking skills within the students, the critical thinking skills are assessed by four indicators namely: (1) making assumptions; (2) drawing conclusions inductively; (3) making decisions; and (4) defining attitudes in solving the problems within the daily life.

Not to mention, the learning process of Chemistry is only conducted by means of information delivery and, consequently, the students have not understood the materials, as part of phenomena that take place around their environment, that the teachers deliver well (Kurniawati, 2013; Riyani et al., 2017; Rohaeti et al., 2009). Departing from the situation, the learning process of Chemistry should have been conducted by using the Contextual Teaching Learning (CTL) Approach by linking the materials to the real-life events. The students are encouraged to view the phenomena that have been taking place around them so that the learning process within the classroom will be more contextual. The Contextual Teaching and Learning Approach refers to the learning approach that links the learning materials, for example the Solubility Product Constant, into the daily life contexts by providing real-life examples such as: (1) the formation of kidney stone; (2) the use of flour in toothpaste; (3) the identification of fingerprint; (4) the phenomena of hard-water; and (5) the formation of stalactite and stalagmite. By doing so, the students might be more motivated in learning and in improving their critical thinking skills. The phenomena that have been taking place might be recorded through contextual videos and these videos, later, might be played during the learning process of Chemistry. The presence of the contextual video might assist the learning process in comparison to the learning process that does not use any contextual video (Kamaruddin et al., 2011). The learning process that has been designed by using the CTL Approach might improve the students' critical thinking skills (Syahbana, 2012).

Another fact about the learning process of Chemistry shows that the teachers have been less variative in using the learning media as the aid for achieving the learning objectives; as a result, the teachers sometimes feel bored (Purwaningsih \& Sugiarto, 2014). The teachers have also been less maximum in utilizing the Information Technology (IT)-based learning media. In the same time, the IT-based learning media that the teachers utilize have not met the standards of the critical thinking skills improvement for the students. In this regard, one of the media that might be utilized is the audiovisual media. In general, audio-visual media refers to the pictures or the animations that contain sounds. This media might clarify the learning materials of Chemistry, which might be abstract, so that it will be easier for the students to understanding the given materials. In other words, the use of the audio-visual media might support and improve the students' learning opportunities in order that the learning quality might be improved as well (Semenderiadis \& Martidou, 2009). One of the benefits that the audio-visual media has is that the audio-visual media might clarify the object that has been too small or, on the other hand, the audio-visual media might shrink the object that has been too big so that the students might learn the given materials well (Daryanto, 2013). 


\section{Psychology, Evaluation, and Technology in Educational Research, 2 (2), 2019, 100}

Khairani Sarwinda, Eli Rohaeti, Mirra Fatharani

The use of the IT-based learning media should be combined with the appropriate learning approach so that the HOTS might be improved (Giavrimis et al., 2011). One of the appropriate approaches that might be combined with the use of the IT-based learning media is the contextual approach, which has been popularly known as the Contextual Teaching-Learning (CTL) Approach. Unfortunately, the intended approach has not been incorporated by the teachers as well. The reason is that within the learning management the teachers have still relied on the use of lecture as their teaching method. Consequently, the students become less motivated in the classroom and since the teachers have relied too much on lecture as their teaching method the learning motivation of the students become low as well during the delivery of the learning materials (Widayanti et al., 2011). Learning motivation refers to the factors within the students' personality which consists of four indicators namely: (1) task selection; (2) student effort; (3) student persistence; and (4) student achievement (Slameto, 2010). In the context of Chemistry, the four indicators will be related to the learning process of Chemistry. The learning process of Chemistry, which links the learning materials to the daily life context through the use of the audio-visual-based learning media in the form of an interactive compact disc (CD), might encourage the students to be more enthusiastic in attending to the learning process. The improving the students' enthusiasm will certainly be able to improve the students' learning motivation. In turn, the high level of learning motivation will help the students to understand the concepts of Chemistry better. In the same time, the development of the computer technology enables the display of any picture or animation that assists the students in understanding the given materials so that the students might perform the learning induction better (Wu \& Foos, 2010).

The materials of the Solubility Product Constant have been delivered by less reliance on the link to the problem-solving activities within the surrounding environment (Ariesta, 2012; Ariesta et al., 2013). Therefore, the learning process of Chemistry might be improved by using the CTL-based audio-visual media within the learning materials delivery. The materials of precipitation within the Solubility Product Constant might be linked to the life of the students by taking the process of the stalactite and stalagmite formation as the real examples in the daily life. The drops of the calciumcontaining water in a long period of time will be precipitated and forms the stalactite and stalagmite. The process of the precipitation and the formation of the stalactite and stalagmite might be illustrated by using the audio-visual media in a short period of time so that the students do not take a long time to understand the formation process. Through such learning process, the students might describe the materials of Solubility Product Constant by using the formation process of the stalactite and stalagmite and perform the critical thinking skills toward the entailing process altogether in the same time.

The elaboration on the problems that have been found in the field has encouraged the researchers to conduct a study on the improvement on the learning process quality by using the contextual approach-based learning media so that the critical thinking skills of the students might be improved. The CTL approach-based learning media might be used for delivering the learning materials of Solubility Product Constant in relation to the daily life contexts of the students. The substance solubility might be described by using the animation within the audio-visual media so that the students might the abstract concept understanding into concrete. The learning process that links the materials of the Solubility Product Constant to the daily life contexts might be expected to make the students more responsive toward the problems in their surrounding environment. The improvement on the students' learning motivation and critical thinking skills might be exercised and be pursued by using the CTL approach-based audio-visual media especially for the materials of Solubility Product Constant.

The development of the audio-visual learning media should be pursued by relying on the CTL approach in order to improve the learning motivation so that the students might exercise their critical thinking skills as one of the HOTS components. The critical thinking skills might be improved by training the students to solve the problems in their daily life through the classroom presentation within the learning process. The audio-visual learning media consists of several indicators that should be met in order that the audio-visual learning media might be implemented within the classroom learning process (Mardhiyah, 2017). These indicators are namely: (1) possessing materials that are in accordance to the learning standards, results and objectives; (2) displaying understandable manuals; (3) interesting topics/problems so that the students will be actively involved within the learning process; (4) using communicative language so that the students will easily understand the learning materials; and (5) displaying the media through interesting colors, pictures, sounds and animations so that the students will be interested to learn. 


\section{Psychology, Evaluation, and Technology in Educational Research, 2 (2), 2019, 101}

Khairani Sarwinda, Eli Rohaeti, Mirra Fatharani

\section{METHOD}

The study was a research and development initiative. Within the conduct of the study, the development of the audio-visual media went through 10 steps of the Research and Development Model by Borg \& Gall namely: (1) preliminary study; (2) product planning; (3) preliminary product development; (4) validation by media expert and material expert; (5) experiment by colleague Chemistry teachers; (6) small-group experiment; (7) product revision based on the small-group experiments; (8) main product experiment; (9) final product revision and development; and (10) final product dissemination (Borg \& Gall, 1983, p. 775). According to the model, the preliminary study should be conducted in the very first place and afterward the preliminary product development should be conducted. The product that should be developed was the CTL approach-based audio-visual learning media. The draft (the first product) of the CTL approach-based audio-visual learning media had been validated by the media expert and the material expert. Then, the results of the validation by both experts were used as the materials for the revision within the further product development. After the revision had been completed, the product that had been revised was sent to an experiment that involved two colleagues and five Chemistry teachers. The revisions and the feedback that had been gathered from the experiment that involved the two colleagues and the five Chemistry teachers were used as the materials for the revision in development of the second product. Next, the second product, namely the CTL approach-based audio-visual learning media, was sent to the small-group experiment. The results of this experiment served as the basis for the revisions within the development of the third product. The third product of the CTL approach-based audio-visual learning media was sent to the experiment that involved the learning process of Solubility Product Constant within the efforts of improving the students' learning motivation and critical thinking skills. The results of the experiment for the third product became the basis in revising and developing the fourth product. Subsequently, the fourth product should be disseminated to the teacher who had been involved within the study.

\section{Subjects}

The experiment of the CTL approach-based audio-visual media was conducted in the State 6 Senior High School Yogyakarta from April $2^{\text {nd }}$ until April 26 ${ }^{\text {th }}, 2014$. Then, the subjects in the study were the students from the State 6 Senior High School Yogyakarta. Within the conduct of the limitedscale experiment, the subjects were 9 students from Grade XI. Furthermore, within the conduct of the field experiment the subjects consisted of two groups, namely the control group and the experiment group, who had been selected from two parallel classrooms of Grade XI. The subjects who had been assigned to the control group were 32 students from Grade XI Science 5, while the subjects who had been assigned to the experiment group were 31 students from Grade XI Science 6. The sample selection for both of the control group and the experiment group was conducted randomly after the normality test and the homogeneity test toward the score of Odd Semester Final Examination in 2013/2014 Academic Year had been completed.

\section{Research Instrument}

\section{Questionnaire Sheet}

The questionnaire sheet was used for gathering the data on the media evaluation/input and on the students' learning motivation. Then, the questionnaire sheet of the CTL approach-based audiovisual media tested 12 indicators, which consisted of 42 assessment aspects. Furthermore, the questionnaire of learning motivation was used for attaining the data on the students' motivation after they had attending the learning process of Solubility Product Constant by using the CTL approachbased audio-visual media that had been developed. The statements within the questionnaire were developed in accordance to the four factors of learning indicators that had been elaborated into 25 statements that the students should complete. These indicators included task selection, student effort, student persistence and student achievement.

\section{Observation Sheet}

The observation sheet was used for gathering the data on the learning motivation and the implementation of the audio-visual learning media. In addition to the use of the questionnaire, the data on the learning motivation might also be attained by using the observation sheet, which consisted of 
10 aspects under observation. The 10 aspects were derived from the four indicators of learning motivation namely: (1) task selection; (2) student effort; (3) student persistence; and (4) student achievement. The observation sheet was completed by the observers through the provision of the checklist mark $(\sqrt{ })$ on the observation sheet of the students' motivation during the learning process. On the other hand, the questionnaire of the audio-visual learning media implementation was used for measuring the implementation of the audio-visual learning media within the learning process of Solubility Product Constant in the classroom. The implementation of the audio-visual learning media was observed by the observers by assigning the checklist mark $(\sqrt{ })$ on the observation sheet of the audio-visual learning media implementation. The observation sheet of the audio-visual learning media implementation consisted of 4 indicators, which had been elaborated into 14 items under observation. The intended indicators in this regard were: (1) learning materials; (2) contextual approach; (3) motivation; and (4) critical thinking skills. The observation was conducted during the learning process of Solubility Product Constant in the classroom.

\section{Critical Thinking Skills Test}

This instrument was used in order to identify the students' critical thinking skills level after the students had attended the learning process of Solubility Product Constant by using the CTL approachbased audio-visual learning media. The type of the test items that had been administered was essay. Then, the test measured four indicators of the students' critical thinking skills in accordance to the experts' opinions. In this regard, the indicators that had been intended were: (1) inductive conclusion drawing; (2) decision-making activities; (3) assumption-making activities; and (4) behaviour-defining activities.

\section{Data Gathering Technique}

The data that had been attained were categorized into two types namely qualitative data and quantitative data. The qualitative data consisted of the feedback that had been provided by the media expert, the material expert, the colleague and the Chemistry teachers for the Senior High School/ Madrasah Ibtidaiyah degree. On the contrary, the quantitative data consisted of the students' learning motivation and the students' critical thinking skills. The data for the motivation questionnaire were attained from the learning motivation questionnaire that had been distributed at the end of the learning process. Then, the data that had been attained were analysed in order to identify the effectiveness of the audio-visual learning media on the improvement of the students' learning motivation. The analysis on the experiment of the CTL approach-based audio-visual learning media was performed by using the Control Group Post-Test Design model and the objective of assigning the model was to measure both the students' learnign motivation and the students' critical thinking skills. The analysis itself was performed by comparing the data that had been attained from the questionnaire that had been distributed at the end of the learning process for both the control group and the experimental group. Then, the qualitative data that had been attained were converted into numbers (scores) for the sake of data description. In addition, the learning motivation was also easured by using the observation sheet of the students' learning motivation so that the questionnaire data that had been compiled by the students and the observation data that had been compiled by the observers on the students' learning motivation might be completed.

Last but not the least, the data on the students' critical thinking skills were attained from the post-test results by means of critical thinking skills test. The post-test items were distributed at the end of the learning process. Afterward, the data of the post-test results on the students' critical thinking skills from both the control group, which was not exposed to the CTL approach-based audio-visual learning media, and the experimental group, which was exposed to the CTL approach-based audiovisual learning media, were compared. The results of the comparison later were able to display the effectiveness of the audio-visual learning media in improving the students' critical thinking skills within the learning process of Solubility Product Constant.

\section{Data Analysis Technique}

\section{Data on the Quality of the Product that Had been Developed}

The data that had been attained from the material expert, the media expert, the colleagues and the Chemistry teachers were tabulated in the score rubric of the Solubility Product Constant audio- 
visual learning media and in the suggestion elaboration. Then, the data from the suggestion elaboration were summarized and concluded so that the data might serve as the basis for revising every component within the Chemistry learning media that had been designed. The development of the audio-visual media itself relied on the use of descriptive analysis with the following the steps: (1) converting the scores assigned by 5 Chemistry teachers from the qualitative form into the quantitative form by using the Likert scale; (2) calculating the mean score of each aspect; (3) converting the mean score of each aspect into the qualitative form by using the criteria of the 4-scale rating category (Direktorat Pembinaan SMA, 2010, p.18); (4) calculating the quality of each assessment aspect that had been developed; (5) calculating the overall score of the learning media quality for the learning materials of Solubility Product Constant by usng the mean score of all assessment indicators; and (6) converting the qualitative value in accordance to the criteria of the ideal assessment category.

\section{Critical Thinking Skills Analysis}

The students' critical thinking skills within the learning process of Chemistry were analysed by viewing the achievement score that each student had attained. The score referred to the sum of the total score from each assessment component. From each assessment component, the data were analysed by using the percentage of success in equation (1).

$N_{K}=\left(\frac{N_{A}}{N_{T}}\right) \times 100 \%$

Note:

$N_{K}=$ The achievement of the students in certain skills

$N_{A}=$ The score that the students had achieved in a skill

$N_{T}=$ The maximum score that the students had achieved

Observation on the Learning Media Implementation

The data that had been attained from the observation sheet were marked $(\sqrt{ })$ for the observed descriptors that had been identified and (-) for the observed descriptors that had not been identified. Then, the score for each component in each meeting was calculated. The percentage scale for determining the learning media implementation was calculated by using the formula in the equation (2).

$\%$ achievement $=\frac{\sum \text { implemented }}{\sum \text { descriptors }} \times 100 \%$

Analysis on the Students' Learning Motivation and the Students' Critical Thinking Skills

The analysis on the students' learning motivation and the students' critical thinking skills was conducted by using the data from the students' post-test score. Then, a test toward the differences between the students' learning motivation and the students' critical thinking skills was conducted and the hypotheses over the results of the test were formulated. Afterward, the test on the intended differences was performed by using the MANOVA statistical test. The requirements that should be met were applied in the MANOVA statistical test and the requirements were the data normality test and the data homogeneity test.

The normality test aimed at identifying the data normality so that the data might be used as the guideline in the selection of either parametric or non-parametric test. The normality test was related to the normality of the data that had been taken from the questionnaire of the students' learning motivation and the questionnaire of the students' critical thinking skills. Then, the normality test was conducted by using the Kolmogorov-Smirnov statistical test with the SPSS 16.00 program. The data were considered normal when the probability value had been higher than 0.05 .

On the other hand, the homogeneity test aimed at identifying whether the samples that had been gathered from the given population were homogenous or not. In this regard, the analysis departed from the conduct of the multivariate homogeneity test first. The homogeneity test toward the students' learning motivation and the students' critical thinking skills was performed by using the Box's M Test, while the homogeneity test for the covariance of the students' learning motivation and the students' critical thinking skills was conducted separately by using the Levene's Test. The samples were considered as coming from the homogeneous population at the significance rate $5 \%$ when the 


\section{Psychology, Evaluation, and Technology in Educational Research, 2 (2), 2019, 104}

Khairani Sarwinda, Eli Rohaeti, Mirra Fatharani

probability value within the calculation exceeded 0.05 . In overall, the homogeneity test was run by using the SPSS 16.00 program.

Eventually, the MANOVA test was conducted in order to measure the students' learning motivation and the students' critical thinking skills between the control group and the experimental group. The objective of conducting the MANOVA test was to identify whether there had been differences on the implementation of the CTL approach-based audio-visual media or not with regards to the improvement of the students' learning motivation and the students' critical thinking skills. Similar to the previous tests, the MANOVA test was conducted by using the SPSS 16.00 program.

Within the study, there was a comparison toward the learning motivation scores and the critical thinking skills scores between the students who had been exposed to the CTL approach-based audio visual media and the students who had not been exposed to the CTL approach-based audio visual media within the learning process of Solubility Product Constant in the classroom. The conclusions within the conduct of the study were accepted or denied according to the following requirements: (1) the null hypothesis (Ho) was denied while the alternative hypothesis (Ha) was accepted when the significance value had been lower than 0.05 ; and (2) the null hypothesis (Ho) was denied while the alternative hypothesis (Ha) was accepted when the significance value had been higher than 0.05 . Both of the null hypothesis and the alternative hypothesis might be consulted in the following section:

First Hypothesis

Ho: There are not any significant differences on the students' learning motivation and the students' critical thinking skills between the control group and the experimental group.

Ha: There are any significant differences on the students' learning motivation and the students' critical thinking skills between the control group and the experimental group.

Second Hypothesis

Ho: There are not any significant differences on the students' learning motivation between the control group and the experimental group.

Ha: There are any significant differences on the students' learning motivation between the control group and the experimental group.

Third Hypothesis

Ho: There are not any significant differences on the students' learning motivation and the students' critical thinking skills between the control group and the experimental group.

Ha: There are any significant differences on the students' learning motivation and the students' critical thinking skills between the control group and the experimental group.

\section{RESULTS AND DISCUSSIONS}

\section{Assessment on Each Aspect}

Aspects of Learning Material

According to the material expert, the CTL approach-based audio-visual media has been scored 19.00 in total. Then, according to the colleagues, the CTL approach-based audio-visual media is scored 19.00 as well. Last but not the least, according to the Chemistry teachers the CTL approachbased audio-visual media is scored 17.00. These scores should be converted based on the assessment score conversion (Mardapi, 2008), which might be consulted in Table 1. Then, departing from these scores it might be concluded that according to the material expert, the colleagues and the Che-mistry teachers the CTL approach-based audio-visual media has fallen into the "Very Good" category. The data on the percentage of the total assessment score by the material expert, the colleagues and the Chemistry teachers in terms of materials might be consulted in Figure 1.

Table 1. Assessment Scale

\begin{tabular}{cc}
\hline Quality & Score \\
\hline Very Good & 4 \\
Good & 3 \\
Poor & 2 \\
Very Poor & 1 \\
\hline
\end{tabular}




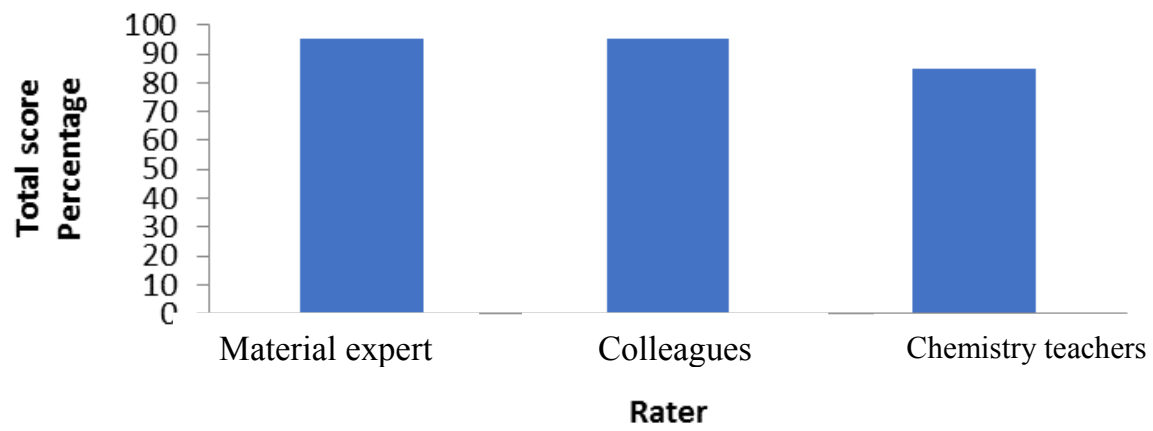

Figure 1. Diagram of the Assessment Results for the Aspect of Learning Material

\section{Aspects of Contextual Approach}

With regards to the aspects of contextual approach, the CTL approach-based audio-visual media has been scored 14.00 by the material expert, 15.00 by the colleagues and 13.40 by the Chemistry teach-ers. These scores have been converted based on the assessment scale conversion (Table 1). Therefore, it might be concluded that the CTL approach-based audio-visual media has fallen into the "Very Good" category. The data on the percentage of the total assessment score by the material expert, the colleagues and the Chemistry teachers for the aspects of contextual approach might be consulted in Figure 2.

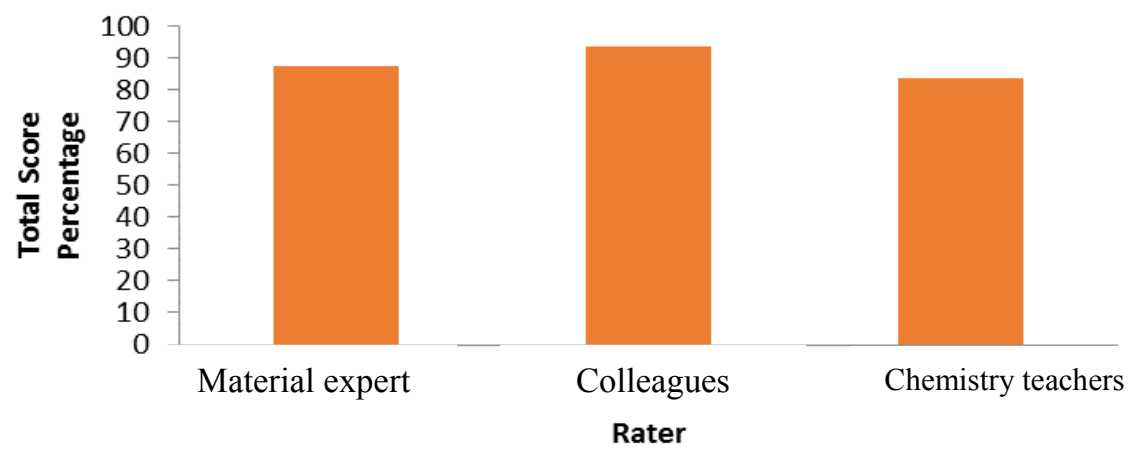

Figure 2. Diagram of the Assessment Results for the Aspects of Contextual Approach

Aspects of Learning Motivation

With regards to the aspects of learning motivation, the CTL approach-based audio-visual media has been scored 12.00 by the material expert, 11.50 by the colleagues and 9.60 by the Chemistry teachers. These scores have been converted based on the assessment scale conversion. Therefore, it might be concluded that the CTL approach-based audio-visual media has fallen into the "Very Good" category based on the assessment results by the material expert and the colleagues. On the other hand, it might also be concluded that the CTL approach-based audio-visual learning has fallen into the "Good" category based on the assessment results by the Chemistry teachers. The data on the percentage of the total assessment score by the material expert, the colleagues and the Chemistry teachers for the aspects of learning motivation might be consulted in Figure 3.

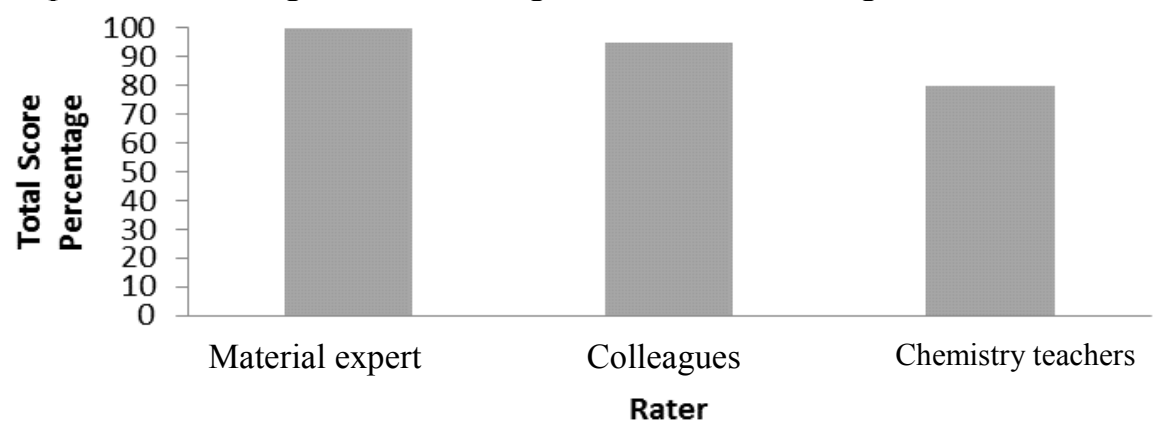

Figure 3. Diagram of the Assessment Results for the Aspects of Learning Motivation 
Aspects of Critical Thinking Skills

With regards to the aspects of critical thinking skills, the CTL approach-based audio-visual media has been scored 11.00 by the material expert, 11.50 by the colleagues and 9.80 by the Chemistry teachers. These scores have been converted based on the assessment scale conversion. Therefore, it might be concluded that the CTL approach-based audio-visual media has fallen into the "Very Good" category. The data on the percentage of the total assessment score by the material expert, the colleagues and the Chemistry teachers for the aspects of critical thinking skills might be consulted in Figure 4.

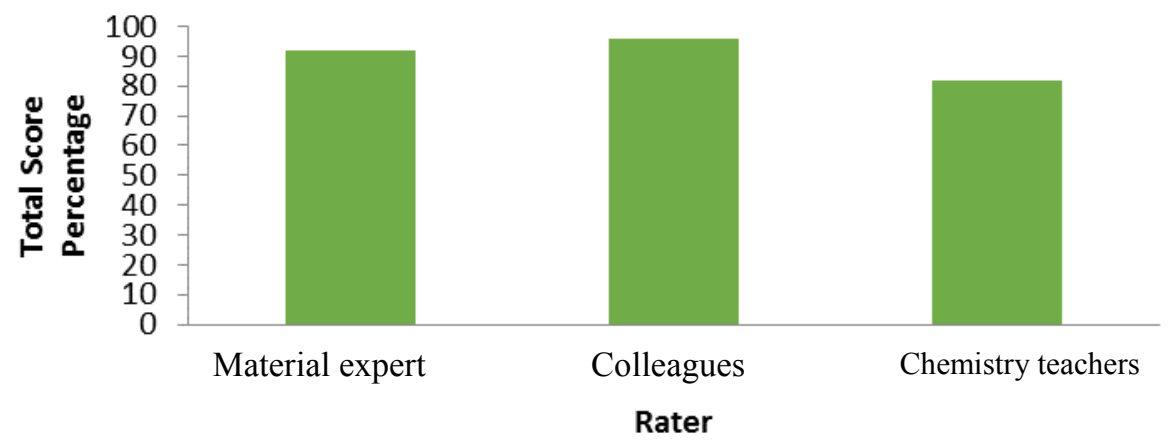

Figure 4. Diagram of the Assessment Results for the Aspects of Critical Thinking Skills

Aspects of Evaluation

With regards to the aspects of evaluation, the CTL approach-based audio-visual media has been scored 15.00 by the material expert, 19.50 by the colleagues and 15.50 by the Chemistry teachers. These scores have been converted based on the assessment scale conversion. Therefore, it might be concluded that the CTL approach-based audio-visual media has fallen into the "Very Good" category based on the assessment results by the colleagues. On the other hand, it might also be concluded that the CTL approach-based audio-visual media has fallen into the "Good" category based on the assessment results by the material expert and the Chemistry teachers. The data on the percentage of the total assessment score by the material expert, the colleagues and the Chemistry teachers for the aspects of evaluation might be consulted in Figure 5.

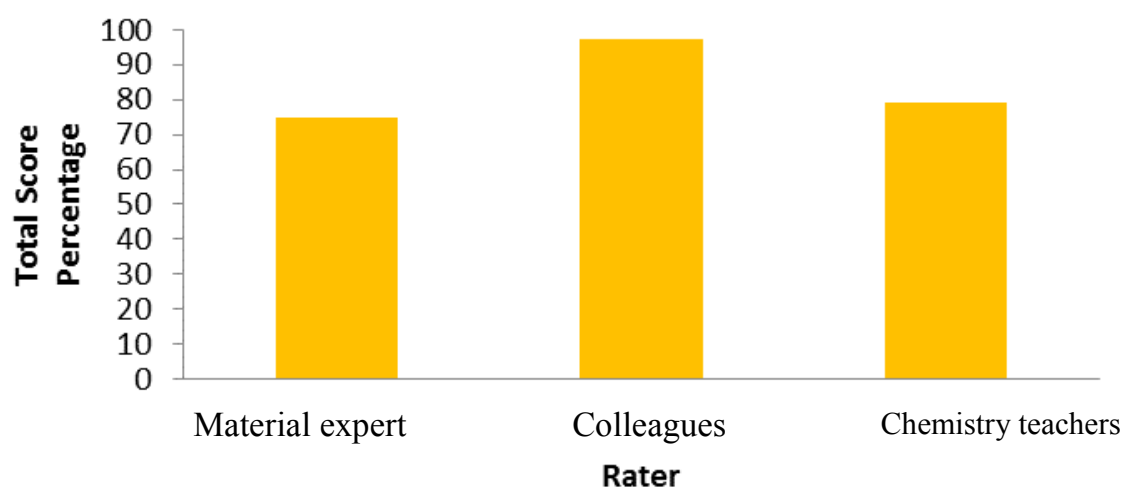

Figure 5. Diagram of the Assessment Results for the Aspects of Evaluation

Aspects of Interface (Opening)

With regards to the aspects of interface (opening), the CTL approach-based audio-visual media has been scored 16.00 by the media expert, 15.50 by the colleagues and 14.00 by the Chemistry teachers. These scores have been converted based on the assessment scale conversion. Therefore, it might be concluded that the CTL approach-based audio-visual media has fallen into the "Very Good" category. The data on the percentage of the total assessment score by the media expert, the colleagues and the Chemistry teachers for the aspects of interface (opening) might be consulted in Figure 6. 


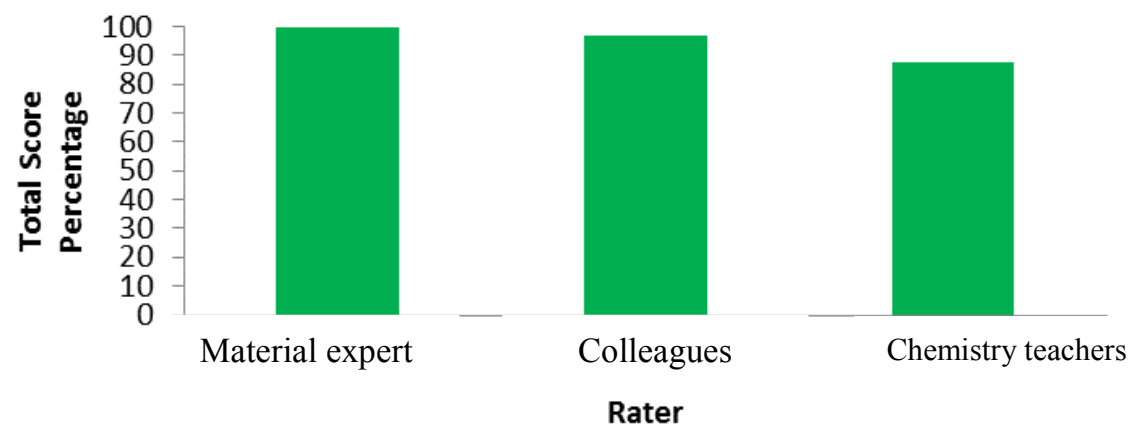

Figure 6. Diagram of the Assessment Results for the Aspects of Interface (Opening)

\section{Aspects of Text/Font}

With regards to the aspects of text/font, the CTL approach-based audio-visual media has been scored 10.00 by the media expert, 10.00 by the colleagues and 9.00 by the Chemistry teachers. These scores have been converted based on the assessment scale conversion. Therefore, it might be concluded that the CTL approach-based audio-visual media has fallen into the "Very Good" category based on the assessment results by the media expert and the colleagues. On the other hand, it might also be concluded that the CTL approach-based audio-visual media has fallen into the "Good" category based on the assessment results by the Chemistry teachers. The data on the percentage of the total assessment score by the media expert, the colleagues and the Chemistry teachers for the aspects of text/font might be consulted in Figure 7.

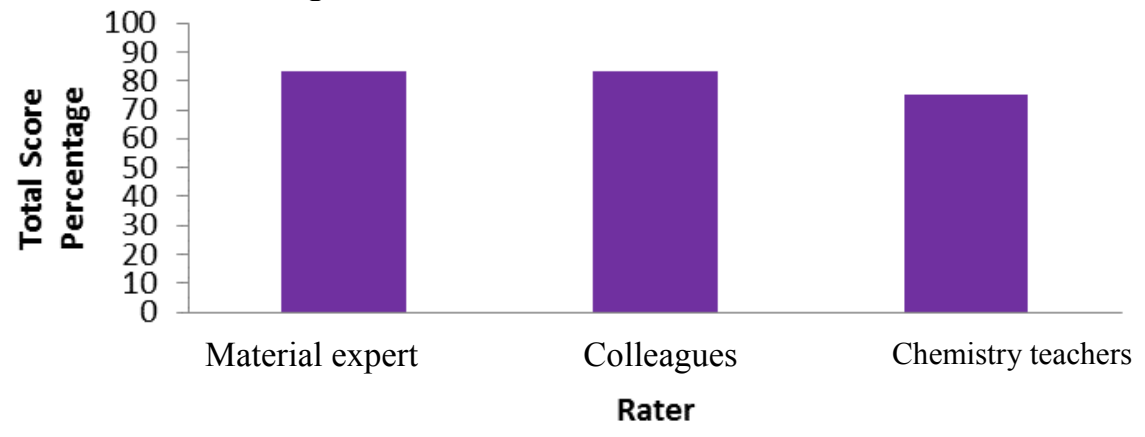

Figure 7. Diagram of the Assessment Results for the Aspects of Text/Font

Aspects of Colour

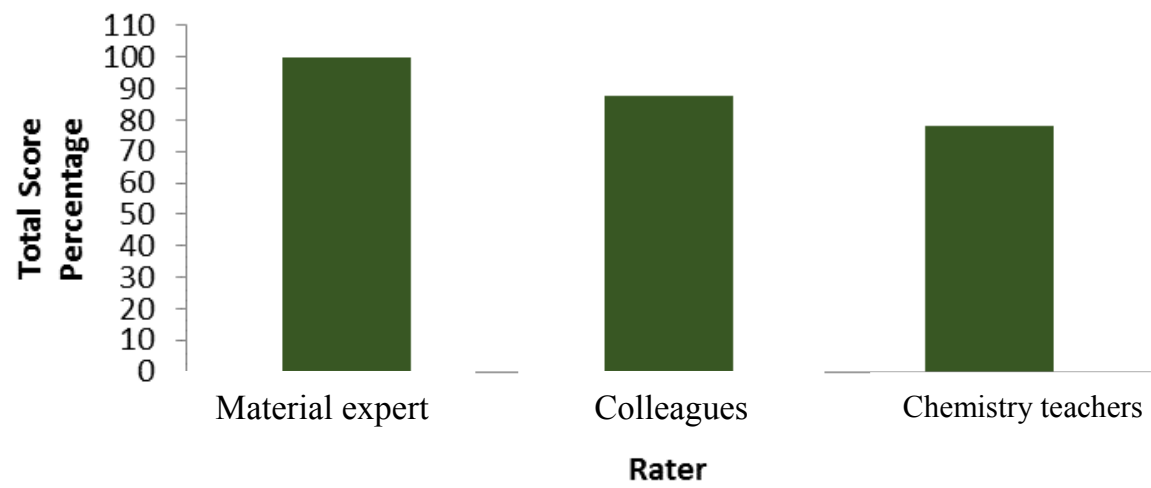

Figure 8. Diagram of the Assessment Results of the Aspects of Colour

With regards to the aspects of colour, the CTL approach-based audio-visual media has been scored 8.00 by the media expert, 7.00 by the colleagues and 6.40 by the Chemistry teachers. These scores have been converted based on the assessment scale conversion. Therefore, it might be concluded that the CTL approach-based audio-visual media has fallen into the "Very Good" category based on the assessment results by the media expert and the colleagues. On the other hand, it might also be concluded that the CTL approach-based audio-visual media has fallen into the "Good" 
category based on the assessment results by the Chemistry teachers. The data on the percentage of the total assessment score by the media expert, the colleagues and the Chemistry teachers for the aspects of colour might be consulted in Figure 8.

\section{Aspects of Picture}

With regards to the aspects of figure, the CTL approach-based audio-visual media has been scored 16.00 by the media expert, 13.50 by the colleagues and 12.00 by the Chemistry teachers. These scores have been converted based on the assessment scale conversion. Therefore, it might be concluded that the CTL approach-based audio-visual media has fallen into the "Very Good" category based on the assessment results by the media expert and the colleagues. On the other hand, it might also be concluded that the CTL approach-based audio-visual media has fallen into the "Good" category based on the assessment results by the Chemistry teachers. The data on the percentage of the total assessment score by the media expert, the colleagues and the Chemistry teachers for the aspects of picture might be consulted in Figure 9.

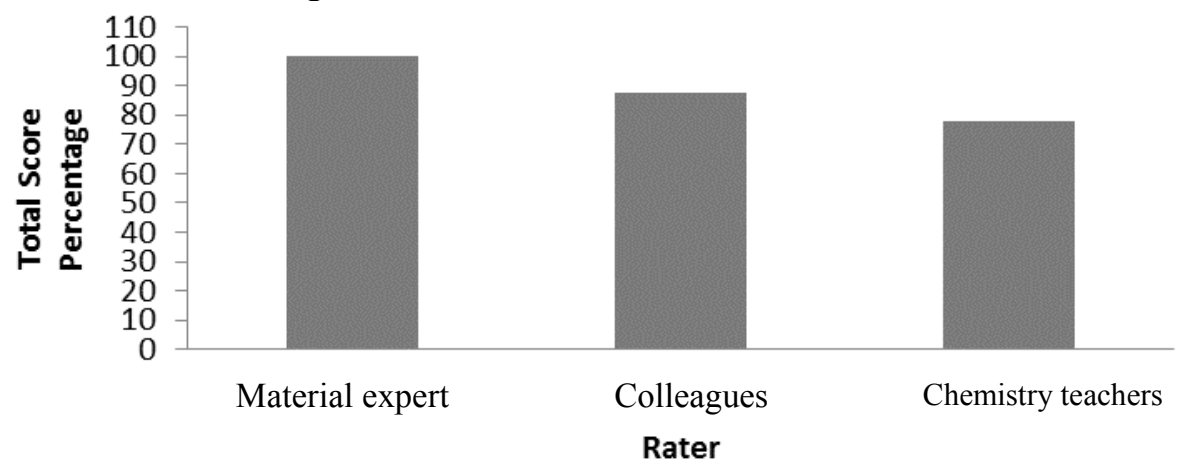

Figure 9. Diagram of the Assessment Results for the Aspects of Picture

Aspects of Sound

With regards to the aspects of sound, the CTL approach-based audio-visual media has been scored 9.00 by the media expert, 10.50 by the colleagues and 9.00 by the Chemistry teachers. These scores have been converted based on the assessment scale conversion. Therefore, it might be concluded that the CTL approach-based audio-visual media has fallen into the "Very Good" category based on the assessment results by the colleagues. On the other hand, it might also be concluded that the CTL approach-based audio-visual media has fallen into the "Good" category based on the assessment results by the media expert and the Chemistry teachers. The data on the percentage of the total assessment score by the media expert, the colleagues and the Chemistry teachers for the aspects of sound might be consulted in Figure 10.

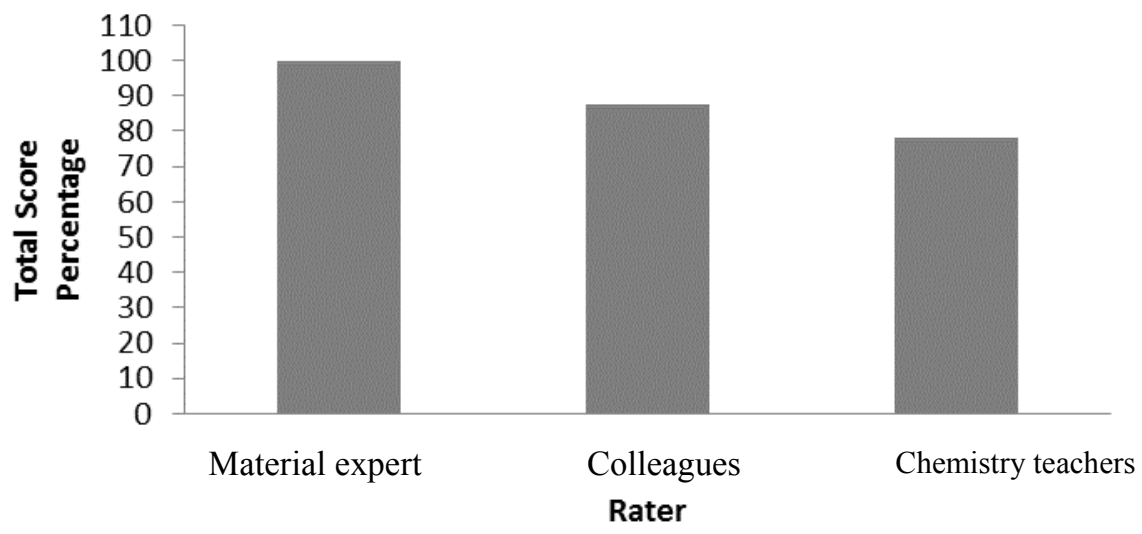

Figure 10. Diagram of the Assessment Results for the Aspects of Sound

Aspects of Animation

With regards to the aspects of animation, the CTL approach-based audio-visual media has been scored 8.00 by the media expert, 7.00 by the colleagues and 6.20 by the Chemistry teachers. These 
scores have been converted based on the assessment scale conversion. Therefore, it might be concluded that the CTL approach-based audio-visual media has fallen into the "Very Good" category based on the assessment results by the media expert and the colleagues. On the other hand, it might also be concluded that the CTL approach-based audio-visual media has fallen into the "Good" category based on the assessment results by the Chemistry teachers. The data on the percentage of the total assessment score by the media expert, the colleagues and the Chemistry teachers for the aspects of sound approach might be consulted in Figure 11.

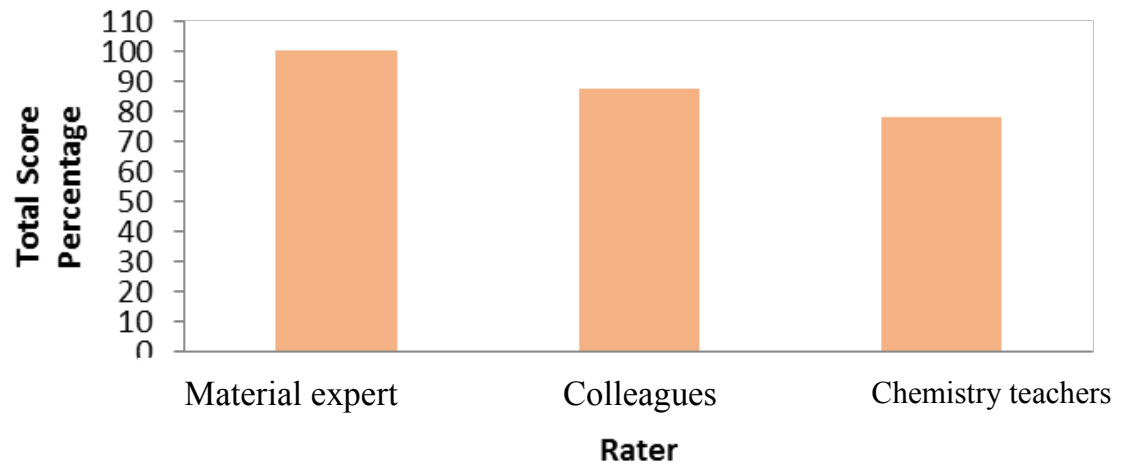

Figure 11. Diagram of the Assessment Results for the Aspects of Sound

Aspects of Language Use

With regards to the aspects of language use, the CTL approach-based audio-visual media has been scored 13.00 by the media expert, 12.00 by the colleagues and 12.60 by the Chemistry teachers. These scores have been converted based on the assessment scale conversion. Therefore, it might be concluded that the CTL approach-based audio-visual media has fallen into the "Very Good" category based on the assessment results by the colleagues. On the other hand, it might also be concluded that the CTL approach-based audio-visual media has fallen into the "Good" category based on the assessment results by the media expert and the Chemistry teachers. The data on the percentage of the total assessment score by the media expert, the colleagues and the Chemistry teachers for the aspects of language use might be consulted in Figure 12.

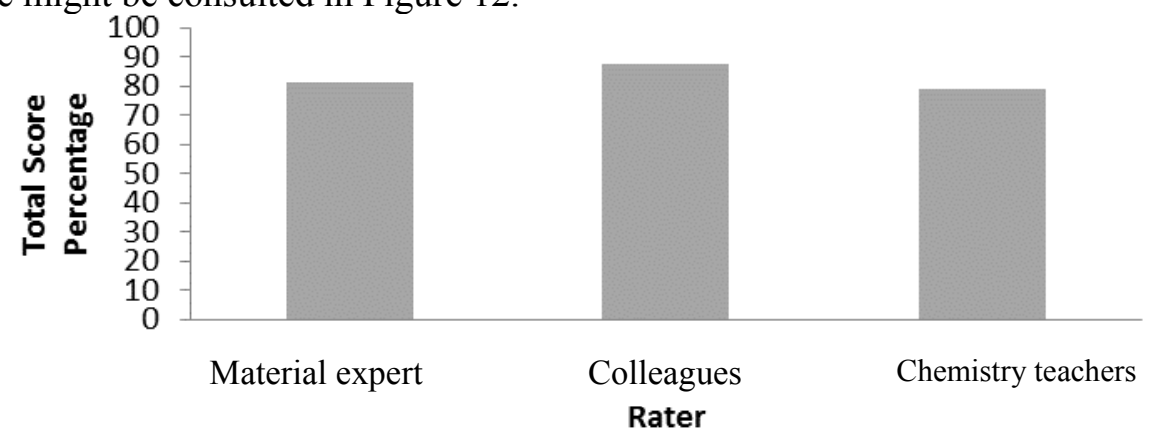

Figure 12. Diagram of the Assessment Results for the Aspects of Language Use

\section{The Implementation of Learning Media in the Classroom}

Based on the data that have been attained from the observation by the observers, it is found that the CTL approach-based audio-visual learning media has been able to meet the 14 aspects of implementation within the conduct of the learning process for the materials of Solubility Product Constant. The four observers have assigned the checklist mark $(\sqrt{ })$ on the column "Yes" for the implementation of the 14 aspects under observation. The statement thus describes that the CTL approach-based audiovisual learning media has been able to meet the 14 aspects of implementation with $100 \%$ completion rate for the Solubility Product Constant materials.

\section{Relationship between the Students' Learning Motivation and the Students' Critical Thinking Skills}

The relationship between the students' learning motivation and the students' critical thinking skills might be tested by using the MANOVA statistical test. The test is conducted in order to identify 
the relationship between the two variables namely the learning motivation and the critical thinking skills. Prior to conducting the hypothesis test, the prerequisite test, namely the normality test and the homogeneity test, should be conducted first. Then, the MANOVA test might be performed when the results of all the tests have met the requirements.

The normality test is conducted in order to identify the whether the data that have been analysed are normally distributed or not. The normality test toward the score of the students' motivation and the mark of the students' critical thinking skills is conducted through the post-test activities. The analysis that has been adopted for the normality test is the Kolmogorov-Smirnov Test by means of SPSS 16.00 program. The results of the normality test show that the Kolmogorov-Smirnov score for the students' normality test is 1.048 while the Kolmogorov-Smirnov score for the students' critical thinking skills is 0.968. Both scores imply that $Z>0.05$ and therefore it might be concluded that the data have been normally distributed. Consequently, the analysis might proceed to the further test.

Furthermore, the homogeneity test is conducted in order to identify whether the samples come from the homogeneous population or not. In conducting the homogeneity test toward the students' learning motivation and the students' critical thinking skills, the Box's M Test has been adopted. According to the results in the Box's M Test, the significance value of the homogeneity test is 0.481 . Therefore, it might be safely concluded that the samples are homogeneous since the significance value is higher than 0.05 .

Eventually, the covariance homogeneity test is conducted as well for identifying the students' learning motivation and the students' critical thinking skills separately. In conducting the covariance homogeneity test, the Levine Test has been adopted by using the SPSS 16.00 program. According to the results in the Levine Test, the significance value of the homogeneity test for the students' learning motivation and the students' critical thinking skills is 0.611 and 0.086 respectively. Thus, it might be safely concluded that the samples have similar variance since the significance value is higher than 0.05 .

The results of the multivariate test show that the significance value is 0.002 . Departing from these results, the null hypothesis (Ho) is denied while the alternative hypothesis (Ha) is accepted since the significance value is lower than $0.05(0.002<0.050)$. In other words, it might be concluded that the CTL approach-based audio-visual learning media has significant influence on the students' learning motivation and the students' critical thinking skills in both the control group and the experimental group. Thus, it might also be concluded that the CTL approach-based audio-visual learning media is able to improve the students' learning motivation and the students' critical thinking skills.

The students' critical thinking skills that have been developed in the CTL approach-based audio-visual learning media are the cognitive skills, the soft skills and the hard skills. The cognitive skills that have been developed in the audio-visual learning media are the students' skills in drawing conclusions inductively within the attitude-taking toward the phenomena that have been taking place in the surrounding environment. Then, the soft skills that have been developed in the audio-visual learning media are the students' skills in making assumptions and making decisions toward the problem-solving efforts. Last but not the least, the hard skills that have been developed in the audiovisual learning media are the students' skills in taking actions toward the problem-solving efforts. In sum, the audio-visual learning media improve the students' interest and, in turn, the high learning motivation might be encouraged in attending to the learning process within the classroom (Noer, 2012). In other words, the learning motivation encourages the learning interest and the curiosity so that the students' soft skills and hard skills might be improved through the interesting learning method (Murni, 2010).

\section{Students' Learning Motivation}

The highest score of the students' learning motivation is found in the experimental group namely 98.00, while the lowest score of the students' learning motivation is found in the control group namely 60.00 . The mean score of the students' learning motivation in the experimental group is higher than the mean score of the students' learning motivation in the control group namely $82.64516>$ 76.78100. The gap of the mean score between the two groups is 5.87000.

The results of the Test of Between Subject Effect for the students' learning motivation show that the significance value is 0.001 . Departing from these results, the null hypothesis (Ho) is denied while the alternative hypothesis $(\mathrm{Ha})$ is accepted since the significance value is lower than $0.05(0.001$ $<0.050$ ). As a result, it might be concluded that there have been differences on the students' learning 
motivation between the control group and the experimental group. Furthermore, departing from the results of the Test of Between Subject Effect, it might be specifically concluded that there have been significant differences on the students' learning motivation between the control group and the experimental group. The experimental group is the classroom that has been exposed to the CTL approach-based audio-visual media while the control group is the classroom that has not been exposed to the CTL approach-based audio-visual media within the learning process of Solubility Product Constant. Departing from these results, it might be concluded as well that the CTL approach-based audio-visual learning media is able to motivate the students in attending to the learning process of Chemistry in the classroom.

The results of the test are in accordance to the observation data that have been attained from the observation sheet of the students' learning motivation. Furthermore, the data from the observation show that in the control group the aspects of completing the task in accordance to the instruction have earned the highest score whereas the aspects of trying to master the use of the audio-visual media have attained the lowest score. On the other hand, the data from the observation show that in the experimental group the aspects of completing the task in accordance to the instruction have earned the highest score whereas the aspects of displaying intensity in sharing opinions, ideas and arguments have earned the lowest score. It is apparent that the students in the control group have less striven to master the use of the audio-visual media and consequently their learning motivation becomes lower in comparison to the students in the experimental group.

As having been implied, the results of the study show that the CTL approach-based audio-visual learning media is able to improve the students' learning motivation. These results are in accordance to the results of the study by Handhika (2012), which report that the learning media that the teachers have implemented is able to trigger the students' motivation, stimulate the learning activities and even provide psychological influence toward the students' achievements. The audio-visual learning media provides illustration that might draw the attention of the students within the learning activities. Such illustration encourages the students to be more motivated in performing the learning activities of Solubility Product Constant.

The CTL approach-based audio-visual media has been designed through the linkages with the problems in the daily-life context such as the stalactite and stalagmite formation, the hard-water phenomena, the kidney stone formation and the fingerprint formation. As a result, the students become more motivated in attending to the learning process of Solubility Product Constant. These results are in accordance to the results of the study by Sumarni and Rahayu (2009), which report that the provision of cases to the students by means of audio-visual media has encouraged the students to be more enthusiastic and more motivated in solving the problems within the given cases. In other words, the audio-visual media might serve as the supporting media for drawing the students' attention so that the learning motivation might be developed. The results of the questionnaire on the students' learning motivation between the control group and the experimental group might be consulted in Figure 13.

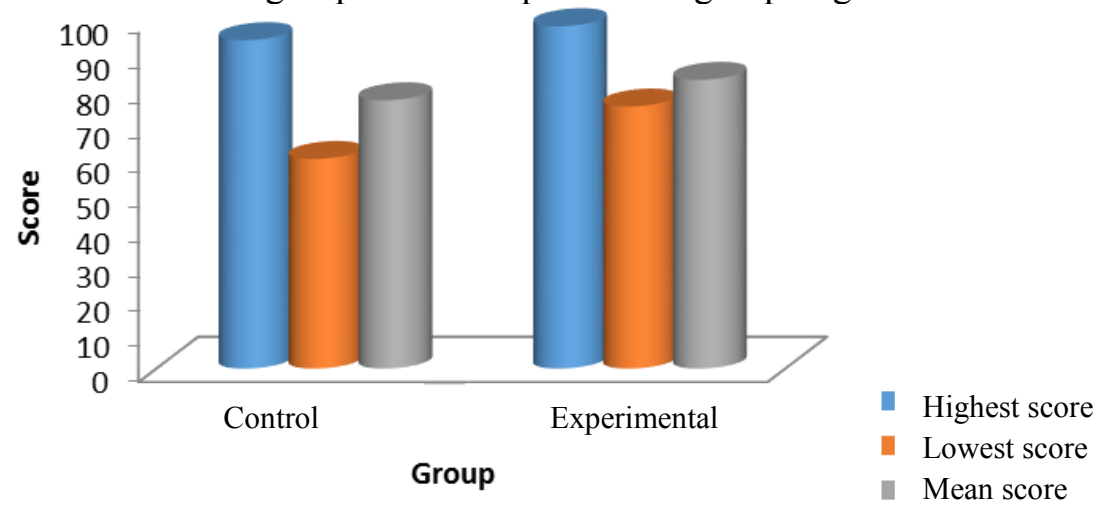

Figure 13. The Score of the Students' Learning Motivation between the Control Group and the Experimental Group

\section{The Students' Critical Thinking Skills}

The highest score of the students' critical thinking skills is found in the experimental group namely 100.00 , while the lowest score of the students' critical thinking skills is found in the control 
group namely 41.70. Then, the mean score on the students' critical thinking skills in the experimental group is higher than the mean score on the students' critical thinking skills in the control group $(83.33>76.10)$. Thus, the gap of the mean score on the students' critical thinking skills between the two groups is 7.23 .

The number of the students who have met the minimum passing grade in the experimental group is 25 people, while the number of the students who have met the minimum passing grade in the control group is 20 people. On the contrary, the number of the students who have not met the minimum passing grade in the experimental is 6 people while the number of the students who have not met the minimum passing grade in the control group is 12 people. The overall number of the students in the experimental group is 31 people, while the overall number of the students in the control group is 32 people. Thus, the percentage of the learning achievement in the experimental group is higher than the percentage of the learning achievement in the control group $(81.00 \%>62.00 \%)$.

The results of the Test of Between Subject Effect for the students' critical thinking skills show that the significance value is 0.044 . Departing from these data, the null hypothesis (Ho) is denied while the alternative hypothesis $(\mathrm{Ha})$ is accepted since the significance value is lower than $0.05(0.044$ $<0.050$ ). Thus, the implication is that there have been differences on the students' critical thinking skills between the experimental group and the control group. Furthermore, based on the results of the Test of Between Subject Effect it might be specifically concluded that there have been significant differences on the students' critical thinking skills between the experimental group and the control group. Thereby, it is apparent that the CTL approach-based audio-visual learning is able to improve the students' critical thinking skills.

As having been implied, the CTL approach-based audio-visual media is able to improve the students' critical thinking skills because the media contains illustrations on the stalactite and stalagmite formation, the hard-water phenomena, the kidney stone formation and the fingerprint formation. As a result, the students are stimulated to make assumptions and draw conclusions inductively toward those phenomena. In turn, the students become able to make decisions and take attitudes toward the problem-solving efforts in their life. These results are in accordance to the study by (Fathan \& Liliasari \& Rohman, 2013), which report that the use of multimedia is able to improve the students' critical thinking skills.

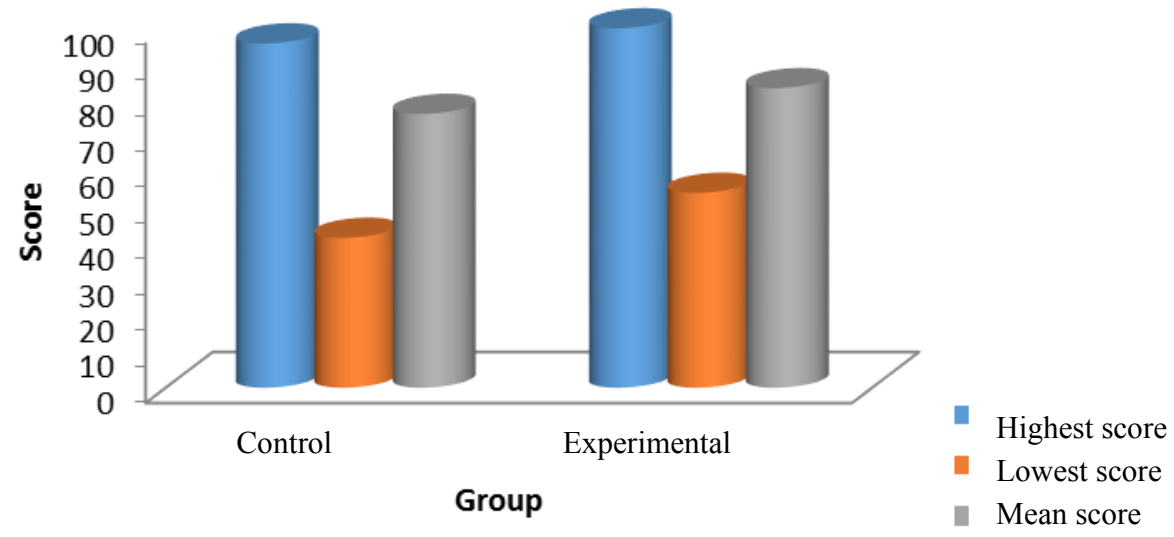

Figure 14. The Score on the Students' Critical Thinking Skills between the Control Group and the Experimental Group

The CTL approach-based audio-visual media provides animated visualization with regards to the influence of common ion on the substance solubility and the influence of $\mathrm{pH}$ on the substance solubility. The visualization by means of animation has made the students able to imagine the abstract concepts so that those concepts become more understandable. The learning process that provides the learning experiences in the form of animation or simulation through the visualization is able to develop the abstraction skills, the language skills and the symbolic skills so that the students' critical thinking skills might be improved within the decision-making activities (Sudarmin, 2012). Such skills might be used by the students as their equipment in solving the problems in the daily-life context. The assessment results for the students' critical thinking skills between the control group and the experimental group might be consulted in Figure 14. 


\section{Psychology, Evaluation, and Technology in Educational Research, 2 (2), 2019, 113}

Khairani Sarwinda, Eli Rohaeti, Mirra Fatharani

\section{CONCLUSIONS}

The CTL approach-based audio-visual media has been successfully developed by using the Borg \& Gall Model. The product, namely the CTL approach-based audio-visual media, is valid for implementation among the students of Grade XI Science in both Senior High School degree and the Madrasah Ibtidaiyah degree since the product has gone through the validation process. The quality of the CTL approach-based audio-visual media that has been developed in general has fallen into the "Very Good" category based on the results of the evaluation by the material expert, the media expert, the colleagues, the Chemistry teachers and the limited experiment. These findings thus confirm that the CTL approach-based audio-visual learning media is feasible for implementation as the learning media for the learning process in Chemistry.

The use of the CTL approach-based audio-visual media is able to improve the students' learning motivation and the students' critical thinking skills. The statement has been confirmed by the questionnaire results and the student observation sheet. Within the experimental group, the students are more enthusiastic, more interested and happier so that they become motivated in attending to the learning process of Chemistry that makes use of the audio-visual media. Such a high motivation is able to improve the students' critical thinking skills, which has resulted in the learning achievement. Within the experimental group, 25 students have met the minimum passing grade while 6 students have not met the minimum passing grade. On the other hand, within the control group 20 students have met the minimum passing grade while 12 students have not met the minimum passing grade.

The research and development initiative for the CTL approach-based audio-visual learning media has been maximally afforded but, unfortunately, there still have been several limitations that the researchers have encountered within the implementation. For example, the product (the CTL approach-based audio-visual learning media) has only been disseminated to the teachers who have been involved within the conduct of the study. Therefore, the product should be disseminated to the Forum of Subject Teachers (MGMP, Musyawarah Guru Mata Pelajaran) in a wider scale. Not to mention, the product should also be disseminated to the professionals, the publishers and even to the scientific journals.

\section{REFERENCES}

Ariesta, N. (2012). Pengaruh pembelajaran kimia dengan pendekatan CTL (Contextual Teaching And Learning) melalui metode guided inquiry dan proyek terhadap prestasi belajar ditinjau dari kemampuan matematik siswa (Pembelajaran kelarutan dan hasil kali kelarutan kelas XI IP). Universitas Sebelas Maret.

Ariesta, N., Ariani, S. R. D., \& Haryono, H. (2013). Pengaruh pembelajaran kimia dengan pendekatan CTL (contextual teaching and learning) melalui metode guided inquiry dan proyek terhadap prestasi belajar ditinjau dari kemampuan matematik siswa pada materi kelarutan dan hasil kali kelarutan kelas XI IPA SMA. Jurnal Pendidikan Kimia (JPK), 2(3). http://jurnal.fkip.uns.ac.id/index.php/kimia/article/view/1276

Borg, W. R., \& Gall, M. D. (1983). Educational research: An introduction. Longman.

Daryanto, D. (2013). Media pembelajaran: Peranannya sangat penting dalam mencapai tujuan pembelajaran. Gava Media.

Fathan, F., \& Liliasari \& Rohman, I. (2013). Pembelajaran kesetimbangan kimia dengan multimedia interaktif untuk meningkatkan penguasaan konsep dan keterampilan berpikir kritis siswa SMA. Jurnal Riset Dan Praktik Pendidikan Kimia, 1(1), 76-83.

Giavrimis, P., Papanis, E., \& Papanis, E.-M. (2011). Information and communication technologies and development of learners' critical thinking: Primary school teachers' attitudes. International Education Studies, 4(3), 150-160.

Handhika, J. (2012). Efektivitas media pembelajaran IM3 ditinjau dari motivasi belajar. Jurnal Pendidikan IPA Indonesia, 1(2). https://doi.org/10.15294/jpii.v1i2.2127

Kamaruddin, N. K. M., bin Wan Ahmad, W. M. R., Amin, Z. M., \& Alias, M. (2011). A study of the effectiveness of the contextual approach to teaching and learning statistics at the universiti tun hussein onn malaysia (UTHM). International Journal of Arts \& Sciences, 4(25), 305. 


\section{Psychology, Evaluation, and Technology in Educational Research, 2 (2), 2019, 114}

Khairani Sarwinda, Eli Rohaeti, Mirra Fatharani

Kurniawati, W. Y. (2013). Pengembangan alat peraga dan lembar kerja siswa berorientasi konstruktivisme dalam pembelajaran kimia SMA. Prosiding SEMIRATA 2013, 1(1). http://jurnal.fmipa.unila.ac.id/semirata/article/view/850

Mardhiyah, M. (2017). Efektivitas penggunaan media pembelajaran audio visual terhadap motivasi belajar sejarah kebudayaan Islam pada siswa kelas VIII MTs Negeri Gajah Demak tahun ajaran 2016/2017. UIN Walisongo.

Moore, B. (2009). Emotional intelligence for school administrators: A priority for school reform? American Secondary Education, 37(3), 20-28.

Murni, A. (2010). Pengaruh penerapan model pembelajaran student centered learning terhadap hasil belajar dengan motivasi belajar sebagai variabel intervening. Pedagogia Jurnal Ilmu Pendidikan, $8(3), 221-235$.

Noer, A. M. (2012). Peningkatan proses belajar-mengajar kimia melalui pemanfaatan VCD di SMA Muhammadiyah Pekanbaru. Jurnal Pendidikan, https://jp.ejournal.unri.ac.id/index.php/JP/article/view/655

Nurdiyana, T. (2019). Peningkatan kemampuan analisis mahasiswa melalui pendekatan contextual teaching learning (CTL) dalam pembelajaran Pengantar Kependudukan. Vidya Karya, 27(1), 71-78. https://doi.org/10.20527/jvk.v27i1.976

Purwaningsih, H., \& Sugiarto, B. (2014). Penerapan strategi problem posing untuk melatihkan keterampilan metakognitif siswa kelas XI IPA 4 SMA N 1 Sukodadi pada materi pokok hidrolisis garam. UNESA Journal of Chemical Education, 3(2). https://jurnalmahasiswa.unesa.ac.id/index.php/journal-of-chemical-education/article/view/8247

Riyani, A. F., Kusumo, E., \& Harjito, H. (2017). Pengembangan lembar kerja siswa berpendekatan inkuri terbimbing pada konsep kelarutan. Jurnal Inovasi Pendidikan Kimia, 11(2). https://journal.unnes.ac.id/artikel_nju/JIPK/10626

Rohaeti, E., Widjajanti, E., \& Padmaningrum, R. T. (2009). Pengembangan lembar kerja siswa (LKS) mata pelajaran sains kimia untuk SMP. Jurnal Inovasi Pendidikan, 10(1). http://jurnal.fkip.uns.ac.id/index.php/jip/article/view/479

Semenderiadis, T., \& Martidou, R. (2009). Using audiovisual media in nursery school within the framework of the interdisciplinary approach. Synergies Sud-Est Européen, 2-2009, 65-76. https://gerflint.fr/Base/SE_europeen2/rachel.pdf

Slameto. (2010). Belajar dan faktor-faktor yang mempengaruhinya. PT Rineka Cipta.

Sudarmin, S. (2012). Meningkatkan kemampuan berpikir tingkat tinggi mahasiswa melalui pembelajaran kimia terintegrasi kemampuan generik sains. Varia Pendidikan, 24(1), 97-103. http://hdl.handle.net/11617/2338

Sumarni, W., \& Rahayu, K. P. (2009). Efektivitas penerapan metode kasus menggunakan media audio-visual terhadap hasil belajar kimia siswa SMA. Jurnal Inovasi Pendidikan Kimia, 3(1).

Syahbana, A. (2012). Peningkatan kemampuan berpikir kritis matematis siswa SMP melalui pendekatan contextual teaching and learning. EDUMATICA: Jurnal Pendidikan Matematika, 2(1), 45-57. https://doi.org/10.22437/edumatica.v2i01.604

Thompson, C. (2011). Critical thinking across the curriculum: Process over output. International Journal of Humanities and Social Science, 1(9), 1-7. http://www.ijhssnet.com/journals/Vol._1_No._9_Special_Issue_July_2011/1.pdf

Widayanti, F. D., Hw, S., \& Masduki, M. (2011). Peningkatan motivasi belajar siswa pada pembelajaran matematika melalui metode collaborative learning dengan memanfaatkan microsoft Powerpoint 2007 (PTK pada siswa kelas VIII SMP Negeri 3 Mojolaban). Prosiding Konferensi Nasional Penelitian Matematika Dan Pembelajarannya. http://hdl.handle.net/11617/332

Wu, C., \& Foos, J. (2010). Making chemistry fun to learn. Literacy Information and Computer Education Journal, 1(1), 3. 